\title{
INTERPELACIONES AL SANDINISMO DESDE EL CINE NICARAGÜENSE CONTEMPORÁNEO: PALABRAS MÁGICAS DE MERCEDES MONCADA ${ }^{1}$
}

\author{
POR \\ Valeria Grinberg Pla \\ Bowling Green State University
}

En Palabras mágicas: para romper un encantamiento (México/Guatemala/ Nicaragua 2012), Mercedes Moncada Rodríguez interpela el proyecto sandinista, cuestionando sus transformaciones político-ideológicas a partir del triunfo y la consecuente institucionalización del Frente Sandinista de Liberación Nacional (FSLN) en 1979, así como las que resultaron de la pérdida de las elecciones en 1990 y la consiguiente redefinición del mismo. Así, utiliza el cine como medio e instrumento para ejercer una memoria confrontativa, a partir de un diálogo crítico con el discurso del sandinismo tal y como fue articulado audiovisualmente por las producciones cinematográficas del Instituto Nicaragüense de Cine (INCINE), cuyas imágenes en movimiento constituyen el archivo actualizado en Palabras mágicas, a efectos de señalar una traición al interior del sandinismo. ${ }^{2} \mathrm{Al}$ mismo tiempo, la cineasta trabaja con dos imágenes alegóricas de Nicaragua: la figura de la Gigantona y el lago de Managua, cuya iteración a lo largo de la cinta le sirve para articular, visualmente, la idea de que la realidad del país permance inalterada por la Revolución. Así, la película se sostiene en la tensión dramática producida entre dos polos opuestos: por un lado, la

\footnotetext{
Agradezco el apoyo logístico del equipo de investigación del Instituto de Historia de Nicaragua y Centroamérica de la Universidad Centroamericana de Managua (IHNCA-UCA) durante el verano de 2013 y, especialmente, a Adriana Palacios.

2 INCINE jugó un rol crucial en las políticas sandinistas entre 1979 y 1989. Véase al respecto el siguiente comentario de María Lourdes Cortés: "El 19 de julio de 1979, día en que los sandinistas llegaron al centro de Managua, se alcanzó el clímax de la euforia revolucionaria no sólo en Nicaragua, sino en todo el Continente. Como presagio de la importancia que tendrían las imágenes durante la década sandinista, dos de los escritores nicaragüenses más prestigiosos -Sergio Ramírez y Gioconda Belli-, ambos miembros activos del sandinismo, relataron, al recordar ese día glorioso, cómo a través de la pantalla televisiva se reiteraba una vieja imagen cinematográfica: Sandino quitándose y poniéndose su sombrero. Ese mismo día arrancó oficialmente el cine en Nicaragua con la creación de Instituto Nicaragüense de Cine (INCINE)" (302; énfasis mío). Para un estudio detallado de la producción e importancia de INCINE, véase Cortés 313-355.
} 
noción del estancamiento de Nicaragua y, por el otro, el deseo (también la posibilidad frustrada y latente) de cambiar la realidad del país.

No por casualidad, la cinta se cierra con una imagen de archivo del día del triunfo de la Revolución, que Mercedes Moncada llama significativamente "día cero", marcando su valor simbólico como punto de inflexión de la historia. ${ }^{3}$ La película reconoce, de este modo, el gesto fundacional de la Revolución Sandinista, por cierto común a todas las revoluciones, como ya ha señalado Walter Benjamin en sus conocidas tesis Sobre el concepto de la historia, basado en la estrecha relación "[...] entre las naciones, las memorias y los calendarios [desde ...] El "advenimiento de los Estados-nacionales como forma moderna de organización y dominación política [...]" (Vernik). En efecto, la conmemoración anual de los hitos que llevaron a la formación de la nación, conocidas como fechas patrias, que distinguen y organizan los calendarios nacionales, son interrumpidas por aquellos eventos cuyo objetivo es cambiar el curso de la historia, como las revoluciones, las cuales hacen "saltar el continuum de la historia" (Benjamin 703; mi traducción) e instauran su propio calendario -con el objeto de fijar en la memoria cultural la nueva temporalidad-.

Releamos a Benjamin. Como es sabido, sus conocidas tesis conjugan una visión mesiánica con una concepción materialista de la historia, en un tan novedoso como provocador replanteamiento del materialismo histórico a partir de la idea de redención, que le permite criticar las interpretaciones mecanicistas del marxismo y de la historia. Señala Esteban Vernik:

Esta crítica al materialismo histórico vulgar y dogmático se ancla en el uso de la idea de progreso que se desprende de un tipo particular de temporalidad. [...] La temporalidad anclada en la idea de progreso del marxismo vulgar y dogmático, no sólo en el plano especulativo, deja de lado un elemento central en la teorización de Marx, como es el de la dialéctica; sino que en el plano político, está llamada-según la precisa tesis de Benjamin- a la derrota cómplice con el fascismo.

El conformismo frente a la historia lineal de ascendente progreso por parte de este materialismo histórico vulgar y dogmático lo lleva a exonerar cualquier idea de peligro y catástrofe ante la segura marcha de la historia. [...] Para la Revolución, había que increparles a los malos lectores de la obra de Marx.

De manera análoga -y en un gesto (¿inconscientemente?) benjaminianoMercedes Moncada increpa a los comandantes sandinistas corruptos, pero también

3 También la breve reseña de Palabras mágicas publicada el 28 de mayo del 2012 por Especialista Mike en el sitio de crítica de cine www.filmaffinity.com llama la atención sobre el anclaje de la película en la retórica del Frente, según la cual el 19 de julio de 1979 marcó el advenimiento de una nueva era revolucionara en el sentido planteado por Benjamin, para luego desestimar la propuesta de Moncada porque usa el cine con fines político-ideológicos.

Revista Iberoamericana, Vol. LXXXI, Núm. 251, Abril-Junio 2015, 539-553 ISSN 0034-9631 (Impreso)

ISSN 2154-4794 (Electrónico) 
a los que callaron demasiado tiempo por medio de una película que denuncia la temporalidad progresista del sandinismo como una falacia, una derrota cómplice con el autoenriquecimiento neoliberal de Arnoldo Alemán. Las tomas del ingenio azucarero "Victoria de Julio" en ruinas (que la directora nos muestra mientras habla de la corrupción del Frente conocida como la piñata) es la cifra de este engaño, como afirma su voz en off en la misma cinta: "Estas ruinas son mi idea de cómo quedó la imagen del hombre nuevo en ese momento". A través del montaje, Moncada propone que el apoyo económico de Hugo Chávez a Nicaragua por medio de la creación de ALBA de Nicaragua, S.A. (ALBANISA), y en apoyo a Daniel Ortega, es una repetición de la marcha fallida de la historia, porque traza las coordenadas de un progresismo falaz. Ella logra este efecto por medio del paralelismo entre las imágenes de archivo de la inauguración del ingenio azucarero en 1985 y las de la celebración del préstamo de Chávez en el año 2009, así como también en la antítesis entre las tomas del ingenio en ruinas y los discursos inaugurales del mismo con todas sus promesas de progreso. La tesis sobre la historia nicaragüense planteada en Palabras mágicas es que la redención prometida por la Revolución Sandinista fue sólo individual: el falso mesías Ortega sólo se ha salvado a sí mismo. Sin embargo, Mercedes Moncada no renuncia al concepto, es decir al deseo, de la redención. Imágenes de archivo que captan la euforia de la toma de Managua el 19 de julio de 1979 no por casualidad cierran la película: en ese "día cero" - desde el cual la directora lee el devenir histórico del país- late la posibilidad de realización del verdadero cambio revolucionario, como diría Edelberto Torres Rivas. Así, la estructura narrativa es un contrapunto entre la línea del progreso mentiroso, que el aparato propagandístico del gobierno instala en la plaza pública, a través de los diversos medios de comunicación a su alcance, y las marcas del estancamiento del país (el ingenio azucarero abandonado y los muchachos fumadores de piedra son, en el discurso del filme, ruinas involuntarias del hombre nuevo). No está de más señalar que en su crítica del discurso oficial del Frente, Palabras mágicas permanentemente llama la atención sobre el rol fundamental de INCINE como institución y del cine como medio para la circulación del mismo, por lo que una y otra vez interroga la veracidad de las imágenes que éste ha producido. La otra forma de interpelación utilizada por la directora consiste en dialogar con las campañas publicitarias del régimen: por ejemplo, mientras la cámara enfoca la pancarta gigante de Sandino a caballo que adorna la fachada del Palacio Nacional, cuyo pie de imagen reza "Sandino: estamos cumpliendo! Daniel", Moncada imagina a Sandino respondiéndole a Ortega con su famosas palabras sobre la credibilidad de aquellos hombres que no quieren para sí mismos más que el pedazo de tierra en el que serán enterrados al morir.

Todo este planteamiento se expresa a través del montaje que sostiene la película: el contrapunto entre las imágenes de archivo (de la Nicaragua bajo Somoza -colonia del Imperio- y de la nueva Nicaragua) y las de la Nicaragua actual que registra

Revista Iberoamericana, Vol. LXXXI, Núm. 251, Abril-Junio 2015, 539-553 ISSN 0034-9631 (Impreso)

ISSN 2154-4794 (Electrónico) 
Mercedes Moncada. ${ }^{4}$ La tensión dialéctica entre estas versiones audiovisuales de la historia nacional es lo que desenmascara la falacia del progreso del país postulada por Ortega y su neosandinismo. Por esta conciencia y uso del archivo y por su uso del relato fílmico como soporte y motor de la tesis que plantea, Palabras mágicas es una película de una gran conciencia cinematográfica.

Así, la narración, a la vez personal y pública, de la historia del sandinismo en la voz en off de la directora, acompaña el montaje del documental, pero es el montaje mismo el que articula lo previsto por Benjamin en la tesis número cinco: el futuro de una nación libre y justa prometido por la Revolución Sandinista (ahora pasado, fijado en las imágenes que nos muestran cómo ha sido, cómo se ha realizado el sueño) amenaza desaparecer en un presente que no se reconoce en esas imágenes. Mercedes Moncada lee la historia del movimiento sandinista desde el instante de peligro representado por un Daniel Ortega que más que prestarse a ser instrumento de las clases dominantes se ha convertido él mismo en el patriarca de una nueva clase dominante en complicidad con la antigua.

Pero hablemos ahora ya no de la estructura, sino del objetivo de Palabras mágicas. A la ideología-memoria del sandinismo institucionalizado, Moncada opone una memoria anclada en lo mágico-mítico cuyo objeto es liberar la fuerza revolucionaria de Sandino. Todo el filme es un conjuro - palabras e imágenes mágicas-para romper un encantamiento. Si bien, en su interpelación del FSLN, la invocación de Sandino es algo previsible, la utilización del lago de Managua como su alegoría aporta un elemento novedoso a la propuesta, pues permite transformar el lago en un lugar de memoria, desde el cual disputa la legitimidad de los usos de Sandino por parte del gobierno de Ortega.

Por medio de las imágenes del lago, Palabras mágicas reinscribe alegóricamente a Sandino en la memoria como lugar bastardeado de lo nacional. Me explico: el asesinato de Sandino, vinculado en el imaginario a la traición de Somoza, sirve aquí para significar también la traición del FSLN y en consecuencia las repetidas traiciones a Nicaragua. Todo esto queda planteado en la introducción del filme, desde cuyo epígrafe (que reza, contra un fundido en negro: "El agua es el ojo de la tierra: su aparato de mirar el tiempo. Paul Claudel") la directora anuncia su lectura de la historia nicaragüense desde una perspectiva informada por la sensibilidad simbolista de Claudel, quien confiere al agua cualidades místicas. En el siguiente cuadro, también sobre fondo negro, se lee:

4 Las imágenes de archivo fueron tomadas de los documentales Nicaragua, los que harán la libertad (1979; dir. Bertha Navarro), Victoria de un pueblo en armas (1980; dir. Bertha Navarro y Jorge Denti), La insurrección cultural (1980; dir. Jorge Denti), los noticieros de INCINE y Esta Semana.

Revista Iberoamericana, Vol. LXXXI, Núm. 251, Abril-Junio 2015, 539-553 ISSN 0034-9631 (Impreso) 
Sandino, el general de hombres libres,

luchó contra el ejército de ocupación de Estados Unidos en Nicaragua.

Fue asesinado en 1934 por órdenes del general Anastasio Somoza García,

director de la Guardia Nacional.

[fundido a negro y nuevo cuadro]

Entonces empezó la dictadura de la familia Somoza que, apoyada por el gobierno de los Estados Unidos, duró desde 1934 hasta 1979.

Los asesinos de Sandino primero escondieron su cadáver, pero años después tiraron sus cenizas al vertedero de basura de la ciudad:

El lago de Managua.

Así, yendo de lo abstracto a lo concreto y de lo espiritual a lo histórico, para recién ahí pasar a lo sensorial, la directora dirige al espectador hacia una lectura alegórica de la significación del lago: sólo entonces las letras se desvanecen (lo último en desaparecer es la frase "El lago de Managua"). Durante tres segundos sólo se oye el sonido del agua (el sonido precediendo a la imagen) hasta que, finalmente, vemos la primera imagen del lago de Managua: una toma fija que dura veinte segundos (00:01:35-01:01:55) y a la que se agrega una apertura musical de fondo.

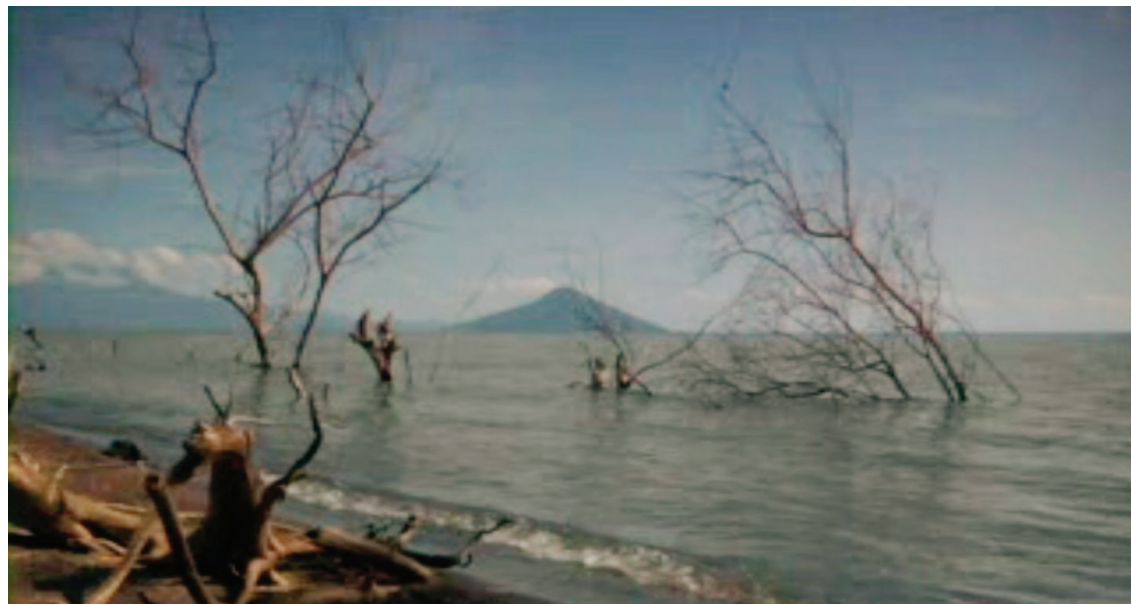

Esta orquestación no deja lugar a dudas sobre la intención de Mercedes Moncada de proponer las imágenes de este lago como lugar de memoria. La explicación que ofrece acto seguido, en off, con una secuencia de planos del lago de fondo, es casi redundante. Cabe notar, sin embargo, que al llamar al lago de Managua por su nombre náhuatl Xolotlán- convoca el pensamiento mágico-mítico premoderno. Así, no sorprende la 
pregunta con la que invita a la audiencia a participar de sus reflexiones: ¿el lago estará poseído por Sandino?

Demos un salto. En la Argentina posdictatorial, el cine ha instalado la imagen del Río de la Plata como representación alegórica de los desaparecidos por la dictadura militar (1976-1983), muchos de cuyos cuerpos fueron arrojados a ese río en los llamados vuelos de la muerte. ${ }^{5}$ En lugar del cadáver (cuya falta material, simbólica y jurídica es significada por esta alegoría), la tumba colectiva representa ominosamente a los desaparecidos porque ya no es posible una lectura inocente del río. En este contexto no es casual la inauguración, en el año 2007, de un Parque de la Memoria precisamente a orillas del Río de la Plata, pero los ejemplos son múltiples. En lo que respecta a Nicaragua, Julia Medina explica,

[...] la "Revolución Sandinista". Como parte de su arsenal ideológico, ha rearticulado un imaginario nacional revolucionario que incluye todo un sistema de códigos: música, arte, colores, simbología e imágenes fotográficas. Entre los símbolos fundacionales de la revolución sandinista se encuentran las imágenes fotográficas del precursor de la lucha, Augusto C. Sandino, cuyas imágenes han sido casi vaciadas de su referente específico (es decir del sujeto biográfico y su contexto histórico); para convertirse, en toda su iconografía, en símbolo de la continuidad de la lucha armada y del nacionalismo anti-imperialista del trayecto histórico aquí referido. Sin embargo, cabe recordad que la Revolución Sandinista ha experimentado varias etapas ideológicas, cada una de las cuales utilizando su propio imaginario visual correspondiente. ("Caricatura" 3)

Frente a la abundancia de imágenes de Sandino que habitan la geografía de Managua desde el triunfo de la Revolución, marcas espaciales del nuevo calendario, pero a las cuales el sandinismo cristiano, socialista y solidario de Daniel Ortega y Rosario Murillo ha investido de nuevos contenidos simbólicos (la serpiente de Quetzalcoatl, el árbol de la vida, la pirámide de luces) o reordenado en nuevos panteones (borrando a ciertos comandantes, incluyendo figuras previamente ausentes en esa narrativa como la de Rubén Darío), el lago representa a Sandino desde lo que esconde su cuerpo. ${ }^{6}$ Así, la ausencia de imagen junto a la referencia al asesinato y posterior ocultamiento del cadáver refiere tanto a la traición como al vaciamiento de sentido inherente a la hipertrofia memorialista revolucionaria. Dicho de otro modo, la alegoría del lago alude a Sandino al tiempo que plantea el problema de su representación, en el cual no es posible deslindar lo simbólico de lo político.

5 Pensemos por ejemplo en Juan, como si nada hubiera sucedido (1987; dir. Carlos Echeverría), Por esos ojos (1997; dir. Gonzalo Arijón y Virgina Martínez), Garage Olimpo (1999; dir. Marco Bechis), o el cortometraje Las aguas del ovido (2013; dir. Jonathan Perel).

6 Para un análisis de la productividad y eficacia de la imagen de Sandino como expresión de la resistencia, véase Medina, "Retrato", 57-74.

Revista Iberoamericana, Vol. LXXXI, Núm. 251, Abril-Junio 2015, 539-553 ISSN 0034-9631 (Impreso)

ISSN 2154-4794 (Electrónico) 
Si la imagen de Sandino ha sido usada profusamente para representar la lucha antiimperialista, ${ }^{7}$ Mercedes Moncada extiende explícitamente la referencia a la ciudad de Managua, y por medio de esta sinécdoque a toda Nicaragua. Como apunta Adriana Palacios, "[e]l lago deviene poética de restos, vertedero, basura, una doble metonimia: ideales y abyección". Este desplazamiento funciona porque en su relato en off, que acompaña las imágenes, la realizadora nos cuenta que el lago es depositario no sólo del cuerpo de Sandino, sino también de los desechos de todos los habitantes de la ciudad: lago-basurero, Sandino (y su legado) cubiertos "de agua" y "de mierda". Hablar de los desechos humanos que van a parar al lago Xolotlán le sirve obviamente para hablar de los despojos de la nación. Y de más está decir que la alegoría extendida continúa, de modo que cuando la directora nos habla de la especie única de peces come mierda que habita el lago de Managua entendemos que alude -no muy indirectamente- a quienes fagocitan el proyecto revolucionario, de la misma manera que lo hacen las repetidas tomas de pájaros carroñeros que pueblan el filme (más adelante utilizará un gato para representar a Daniel Ortega en el año 2006 y otra vez a zopilotes para referirse a Arnoldo Alemán y sus nuevos aliados).

El lago sirve para representar el estancamiento que atraviesa el país según el veredicto de la directora, pero también, en tanto repositorio, funciona como imagen de la memoria. El tiempo de exposición de la primera toma, la multiciplidad de tomas del mismo que habitan Palabras mágicas, y -sobre todo- el tipo de encuadre que las caracteriza, en el cual salta a la vista la textura del agua, invitan a establecer una conexión no sólo audiovisual, sino también táctil con el agua, más elemento que paisaje. Recordemos en este punto el comienzo del filme, cuyo trazado va de lo intelectual (la palabra escrita que introduce primero lo místico y después lo histórico) a lo sensorial (primero el sonido, después la imagen). En una construcción de la memoria que apela a los sentidos, Mercedes Moncada apuesta por las imágenes hápticas del lago de Managua para sostener la alegoría de la historia estancada de Nicaragua.

A mi entender, la eficacia de las imágenes hápticas como lugares de memoria para culturas de alto contacto como la centroamericana y latinoamericana, residen probablemente en la estrecha relación entre lo sensorial, la memoria y lo afectivo. ${ }^{8}$ Pese a ello, Mercedes Moncada explica con detalle y parsimonia todas sus alegorías. Así, nos dice: "Yo soy como este lago, que no es como un río que fluye y es siempre nuevo,

7 Continuando con esta tradición, Nicaragua... el sueño de una generación (2012), dirigida por Roberto Persano, Santiago Nacif y Daniel Burak, se inicia con las consabidas imágenes de Sandino. Este filme incluye también una interpretación de otro símbolo de lo nacional, la canción Nicaragua, Nicaragüita, la cual culmina con un close-up de la silueta iluminada de Sandino que adorna el edificio del antiguo banco de América en Managua.

8 En Otros mundos, su estudio sobre el nuevo cine argentino, Gonzalo Aguilar nota que muchos realizadores utilizan imágenes hápticas como lugares de memoria.

Revista Iberoamericana, Vol. LXXXI, Núm. 251, Abril-Junio 2015, 539-553 ISSN 0034-9631 (Impreso)

ISSN 2154-4794 (Electrónico) 
sino que guardo y acumulo". Hacia el final, la realizadora se preguntará nuevamente por el fluir del lago, la memoria, la historia, pero ahora, en este punto, hay un close-up del agua del lago en movimiento, música de fondo (los primeros acordes de Managua, Nicaragua is a beautiful town) -siempre el sonido precediendo a la imagen-, y se da inicio al relato de la historia de Nicaragua (siempre en la voz de Moncada), desde la era somocista hasta la actualidad, a partir de imágenes de archivo. Todas las citas audiovisuales están marcadas como tales porque aparecen encuadradas sobre fondo negro, en un recorte - literal y simbólico- de la pantalla. La primera secuencia es un videoclip al son del ya citado tema de Guy Lombardo que retrata irónicamente la dolce vita durante la dictadura de los Somoza. La transición de blanco y negro a color al interior del videoclip marca la irrupción de la lucha armada con el objeto de derrocar a Somoza. Mientras las primeras imágenes forman parte de los noticieros somocistas, las últimas ya forman parte del cine insurreccional que acompañó el proceso revolucionario en Nicaragua. La última imagen del clip, una toma movida, filmada con cámara en mano, en la que se ven algunos guerrilleros en una barricada, lleva la inscripción "Junio de 1979" seguida de "un mes antes del Día cero", dando -como expliqué al comienzo de este trabajo- la pauta de lectura de la historia propuesta por Palabras mágicas. Luego se oye una explosión y toda la pantalla queda en blanco, primero se oye el viento, después el piar de algún pájaro hasta que poco a poco la bruma se disipa, cediendo paso a una imagen háptica de un cielo tormentoso. Sobre este fondo se lee, finalmente, el título de la película. Evidentemente, el esquema narrativo vuelve a repetirse: de la reflexión filosófica a la referencia histórica (esta vez audiovisual) y de ahí a lo sensorial, que va más allá de la mera imagen. No sorprende entonces que la directora dé cuenta explícita de la capacidad de las percepciones sensoriales para activar la memoria, al comentar más adelante en el transcurso del filme: "Cuando estoy en Managua, primero la noto en los sentidos. La humedad, el calor, el sudor y el polvo traen de nuevo los recuerdos".

La otra imagen alegórica de Nicaragua con la que trabaja Moncada es la de la Gigantona. La primera vez la vemos en un plano medio, a la izquierda del cuadro, de espaldas a la cámara pero de frente al lago - es decir frente a la memoria-, sobrevolada por ominosos zopilotes. Su vestido tiene los colores de la bandera nicaragüense, lo cual, junto al parlamento simultáneo de la realizadora, no deja lugar a equívocos con respecto a su carácter alegórico. El relato en off nos lleva hasta la época de formación de los lagos y volcanes de Nicaragua para reflexionar desde ahí sobre la pequeñez de la historia (humana, política) en el marco de las eras geológicas. Por medio de esta referencia a un posible fin de la historia a causa de un desastre natural, Mercedes Moncada no sólo inviste de urgencia a sus preguntas abiertas sobre el futuro de Nicaragua, sino que también alude a los estragos naturales del pasado, cuyas imágenes (respectivamente, las del terremoto de 1972 y del Huracán Mitch en 1998) también habitan el filme; y en su doloroso recuerdo se asienta el convencimiento de la afirmación: "Sabemos que eso

Revista Iberoamericana, Vol. LXXXI, Núm. 251, Abril-Junio 2015, 539-553 
va pasar". En el momento en el que dictamina "cuando eso ocurra, todo será nada", la cámara hace un close-up del rostro de la Gigantona al cual sobreimprime la imágen del agua del lago en movimiento, hasta cubrirla por completo. Esta toma del vaivén de las aguas del lago y su sonido arrullador se mantiene por varios segundos, apelando nuevamente a las sensaciones hápticas de los espectadores y vinculando de este modo sus percepciones y su memoria afectiva a los contenidos políticos propuestos en el filme por medio de estas alegorías-imágenes mágicas.

Esta primera puesta en escena de la Gigantona es, obviamente, un recurso netamente argumental. La directora la coloca frente al lago con el fin de introducir la alegoría para luego hacerla reaparecer en varias ocasiones, así como una y otra vez inserta imágenes del lago Xolotlán, pues ambas funcionan como superficies (imágenes hápticas) en donde proyectar sus reflexiones sobre el destino de Nicaragua. Además, también vamos a ver otras versiones de la Gigantona que no fueron puestas en escena por Mercedes Moncada. En esos casos su intervención consiste en filmarla o bien en seleccionar imágenes de archivo en donde ocupa un lugar central, que ella se encarga de resaltar a través del encuadre o del montaje.

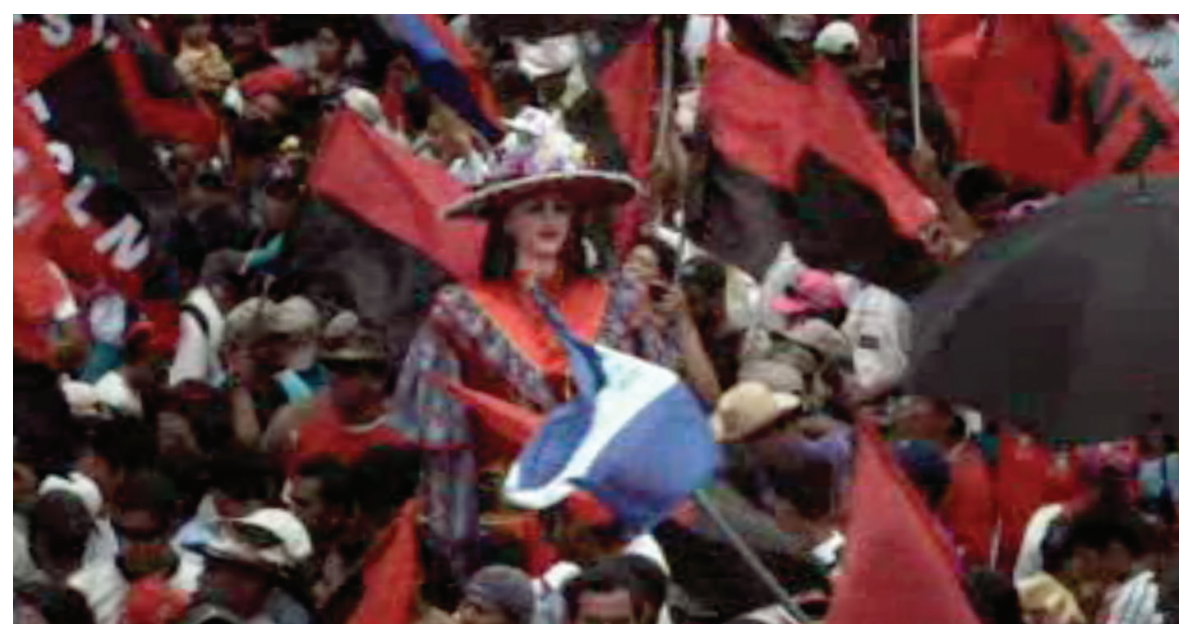

En su conjunto, es el paralelismo entre las imágenes de la era somocista, del triunfo del Frente y de la época actual, en particular las repeticiones de la Gigantona en medio de la multitud, en una escena que parece ser siempre la misma, lo que articula visualmente la tesis de Moncada del estancamiento de Nicaragua. El montaje de Palabras mágicas sugiere que el tiempo cíclico de la religiosidad, el cual aparece en las fiestas agostinas de Santo Domingo de Guzmán (patrono de Managua), se superpone al calendario lineal de la nación política. En vistas del fracaso de las transformaciones

Revista Iberoamericana, Vol. LXXXI, Núm. $251, \quad$ Abril-Junio $2015, \quad 539-553$
ISSN 2154-4794 (Electrónico) 
de la historia en términos de la temporalidad moderna, la película parece indagar las posibilidades de transformación implícitas en la temporalidad mágica del culto popular. La aparición de la Gigantona, agitando los brazos en vaivén, en festividades actuales y de la era somocista, señala un estancamiento porque todavía hay dos celebraciones paralelas en Managua: la de los pobres y la de las clases acomodadas, en la cual las élites se sienten a gusto (lo que es leído por Moncada como un fracaso de la Revolución Sandinista). ${ }^{9}$ No obstante o, mejor dicho, al mismo tiempo hay un atisbo de movimiento en el vaivén de sus brazos y por tanto una posibilidad de cambio. En efecto, mientras que en las escenas de fiestas callejeras la Gigantona baila, la filmación de un festejo reciente del aniversario de la Revolución hace hincapié en su estancamiento. Así, mientras Rosario Murillo empieza vivando al pueblo de Nicaragua para terminar aclamando una y otra vez a Daniel Ortega, ${ }^{10}$ la cámara hace un close-up sobre una Gigantona inmóvil, atrapada en la temporalidad engañosa de un proyecto de transformación política traicionado, al tiempo que Mercedes Moncada explica que la imposibilidad de avanzar se debe a la ausencia de puntos de referencia válidos. Si esta escena es una alegoría de la marcha frustrada de la historia, las imágenes finales de Palabras mágicas, apuntan, por el contrario, a la posibilidad aún latente de progreso en un encuadre de la Gigantona con sus brazos al viento al tiempo que se oye el grito de "¡Viva Nicaragua libre!” durante el festejo de la toma de Managua en 1979.

Ahora bien, el contrapunto entre las imágenes de archivo de películas como Victoria de un pueblo en armas o La insurrección cultural y las tomas de la Nicaragua actual (las cuales desmienten el progreso prometido por la Revolución que pervive trágicamente, como promesa fallida, en las cintas de INCINE) es lo que constituye la clave de una lectura del neosandinismo megalómano de Daniel Ortega como farsa, en el sentido planteado por Karl Marx en su conocido ensayo El 18 Brumario de Luis Bonaparte con respecto de la problemática de la repetición de la historia. ${ }^{11}$ Asimismo, hacia el final

9 La escena en la que un hombre vestido con pantalón y camisa de vestir, anteojos oscuros, teléfono celular al cinto y trago en mano, baila gozoso en una tarima, disfrutando del espectáculo del desfile hípico como espectador privilegiado, expresa muy bien esta idea.

${ }^{10}$ Sus palabras textuales son: “¡Viva el Frente Sandinista de Liberación Nacional! ¡Viva la Revolución Popular Sandinista! ¡Viva la juventud sandinista! ¡Vivan las mujeres! ¡Vivan las mujeres, vivan las mujeres! ¡Viva Daniel! ¡Viva Daniel! ¡Viva Daniel!”

${ }^{11}$ Mercedes Moncada no es la única en interpretar el retorno al poder del sandinismo como farsa. Otro ejemplo de esta postura puede verse en una caricatura de Sandino hecha por Pedro X. Molina, como lo demuestra el análisis de Julia Medina, quien señala que esta caricatura comenta irónicamente la transformación del sandinismo, "reescribiendo, en este caso, la tragedia a la que se alude en la primera imagen [el retrato de Sandino en que se basa la caricatura] y la farsa expuesta en la segunda representación [la caricatura en cuestión]. Sería pertinente entonces citar aquí la famosa observación de Marx en el 18 Brumario de Louis Bonaparte: 'Hegel dice en alguna parte que todos los grandes hechos y personajes de la historia universal aparecen, como si dijéramos, dos veces. Pero se olvidó de agregar: una vez como

Revista Iberoamericana, Vol. LXXXI, Núm. 251, Abril-Junio 2015, 539-553 ISSN 0034-9631 (Impreso)

ISSN 2154-4794 (Electrónico) 
del filme, los acordes de Managua, Nicaragua is a beautiful town que sirvieron para introducir la forma de vida de la clase acomodada en la época somocista acompañan tomas actuales de la injusticia social que aún prevalece en Nicaragua como contraparte del enriquecimiento de Daniel Ortega y sus allegados, estableciendo una correlación irónica entre la corrupción de estos últimos y la de los Somoza.

Desde el punto de vista cinematográfico, hay una escena en particular en la que se articula muy bien la noción de la repetición de la historia como farsa en Palabras mágicas. Se trata de un plano secuencia en el que un muchacho que se define a sí mismo como piedrero - persona adicta al crack- habla sobre su vida directamente a la cámara y luego camina hacia una esquina de la calle en la que hay adoquines apilados de una forma similar a la de las barricadas sandinistas durante la lucha antisomocista. Esta referencia no queda librada a la capacidad de asociación del espectador. Por el contrario, la directora incluye numerosas tomas de esas barricadas y además explica la ironía implícita en el hecho de que la familia Somoza fuera dueña de una fábrica de adoquines -los mismos usados para derrocarlo-. La radicalidad revolucionaria de ese momento histórico se desvanece en su repetición neosandinista, porque los sujetos que la protagonizan (los jóvenes piedreros) lejos de ser heroicos, son marginales. Su marginalidad es evidente en su vida cotidiana, tal como la muestra el documental: el habla, el consumo de drogas, la violencia que marca sus relaciones de género, la aparente vagancia, la indigencia, la omnipresencia de la basura, son todas características opuestas a las del soñado hombre nuevo que la revolución ansiaba producir. No por casualidad, la directora siente la necesidad de proteger las identidades de estos jóvenes ante la cámara (sus caras aparecen fuera de foco, impidiendo toda identificación), lo que implica que, a sus ojos, el mecanismo de la historia puesto en marcha por la Revolución no les ha dado acceso a una ciudadanía plena. En ese sentido, son pertinentes la preguntas que se hace Adriana Palacios:

\begin{abstract}
¿Sugiere acaso la realizadora que son estas juventudes, ciudadanías, la consecuencia más abyecta de la revolución? ¿Son ellos solamente máquinas de muerte o violencia activadas por los partidos políticos -en su caso alude al FSLN-en momentos de tensión y crisis provocadas por los procesos electorales? ¿No es acaso esta representación una re-basurización de estos jóvenes?
\end{abstract}

Pero volvamos a lo que ocurre en la escena de los muchachos piedreros filmada por Moncada. En el momento en el que el joven que acaba de hablar frente a la cámara se acerca a sus compañeros, se ve una pintada en el caraterístico color rosa del neosandinismo de Ortega, la cual fue recubierta de grafiti. La propaganda

tragedia y la otra como farsa' (15; mi traducción). Sin querer pronunciarme en cuanto a la travesía del sandinismo, esta frase sintetiza indudablemente el comentario inscrito en la caricatura" ("Caricatura" 6).

Revista Iberoamericana, Vol. LXXXI, Núm. 251, Abril-Junio 2015, 539-553 ISSN 0034-9631 (Impreso)

ISSN 2154-4794 (Electrónico) 
de Ortega como telón de fondo de las subjetividades antiheroicas de los jóvenes piedreros permite leer esta escena como un comentario crítico sobre las mutaciones ideológicas del FSLN y su incapacidad de transformar la sociedad para que todos los hombres y mujeres tengan acceso a los beneficios de la ciudadanía plena. En efecto, y como vimos, desde la perspectiva de la realizadora, estos jóvenes son la antítesis del hombre nuevo. Por cierto, la analogía entre los muchachos piedreros y los guerrilleros sandinistas se acentúa cuando nos enteramos de que los primeros son contratados como fuerza de choque por el gobierno sandinista para reprimir ilegalmente a los liberales en manisfestaciones públicas, triste farsa del ejército de hombres libres.

Con esta polémica intervención en el espacio público de la posguerra y del neosandinismo posrevolucionario, Mercedes Moncada se suma a las muchas voces desencantadas con el sandinismo. ${ }^{12}$ Lo novedoso en este contexto no es la crítica a Daniel Ortega y a la conducción del FSLN, sino la puesta en escena de dos imágenes alegóricas de la nación -el lago de Managua, la Gigantona-desde las cuales interpelar, a modo de conjuro, pasado, presente y futuro del país. Dicho de otro modo, su aporte consiste en acuñar un lenguaje audiovisual de la memoria traicionada. Justamente porque no es la única, vale la pena pensar la perspectiva de Palabras mágicas en relación con la mirada retrospectiva de otros realizadores que, como Mercedes Moncada, evalúan el proceso revolucionario desde el presente: el director sueco Peter Torbiörnsson con Last Chapter: Goodbye Nicaragua! en el 2010 y los cineastas argentinos Roberto Persano, Santiago Nacif y Daniel Burak con Nicaragua... el sueño de una generación en el 2012.

Goodbye Nicaragua! comparte con Palabras mágicas el uso del cine para indagar en el pasado desde una subjetividad herida. Aunque ambos directores coinciden en una interpelación al sandinismo desde el desencanto, Moncada nos habla de una traición colectiva a Nicaragua de la que ella también fue víctima, mientras Torbiörnsson hace lo contrario: él parte de su trauma personal para concluir que su experiencia es sintomática del fracaso de la Revolución. ${ }^{13}$ En palabras de Ileana Rodríguez y Antonio Gómez, "la

12 Piénsese por ejemplo en la creación, en 1995, del Movimiento Renovador Sandinista (MRS) o en publicaciones como Vuelo de cuervos (1997) de Erick Blandón y Adiós muchachos (1999) de Sergio Ramírez, que ajustan cuentas con el sandinismo desde la escritura literaria.

13 "En mayo de 1984, un grupo de periodistas internacionales, consiguen una conferencia de prensa con Edén Pastora, ex combatiente sandinista, disidente y líder de la ofensiva contra. El encuentro se hizo en una pequeña choza en la ribera norte del río San Juan, en la frontera con Costa Rica. Apenas comenzada la sesión de preguntas y respuestas, estalló una bomba que dejó un saldo de cuatro muertos y veinte heridos. El ataque fue inicialmente achacado a la CIA, pero un tiempo después se hizo evidente que se trataba de una operación de la inteligencia nicaragüense, y se pudo identificar a su responsable material: Vital Roberto Gaguine, un revolucionario argentino, miembro del Ejército Revolucionario del Pueblo y del Movimiento Todos por la Patria, que viajaba bajo la falsa identidad de Per Anker Hansen, fotógrafo danés. Hansen había sido incluido en el grupo por mediación de Torbiörnsson. Torbiörnsson sabía que

Revista Iberoamericana, Vol. LXXXI, Núm. 251, Abril-Junio 2015, 539-553 
película pareciera proponer que la pálida Revolución traiciona con el mismo pie a los solventes intelectuales europeos y a los pobres campesinos nicaragüenses". Debido a su rol involuntario en el atentado fallido a Edén Pastora, el realizador sueco ejerce una memoria confrontativa desde la culpa y en busca de la redención personal, ocupando la escena, interpretando la historia en función de su experiencia individual y desplazando a Nicaragua, la preocupación central de Mercedes Moncada, del centro de la atención.

Por su parte, el documental Nicaragua... el sueño de una generación establece tanto con INCINE como con el FSLN una relación diametralmente opuesta a la de Palabras mágicas. Si Moncada usa la producción fílmica de INCINE para hacer visibles las grietas en el discurso oficial sandinista sobre el progreso del país, Persano, Nacif y Burak se valen de estas imágenes, así como también del relato nostálgico de las diversas personas entrevistadas, para afirmar la continuidad de los valores revolucionarios a treinta años de la toma de Managua. De manera significativa, ambas películas muestran escenas de la plaza en el 30 aniversario de la Revolución. La gran diferencia consiste en que Nicaragua ... el sueño de una generación cierra con tomas de una muchedumbre jubilosa detrás de la cual se lee la pancarta oficial: "SEGUIMOS DE FRENTE CON EL FRENTE". Entre las muchas caras y gestos de felicidad que capta, la cámara se detiene también en un hombre con una camiseta con la siguiente inscripción: "FSLN defendiendo nuestras victorias! Daniel". Por el contrario, y como he comentado más arriba, Mercedes Moncada establece un contraste entre la plaza de la victoria en julio de 1979 y la plaza del neosandinismo posrevolucionario, a partir del papel que tiene en ella la Gigantona. Hay muchos más ejemplos de las diferencias en la interpretación de escenas muy similares en estas dos películas, tanto en el caso de tomas actuales como en el de imágenes de INCINE. Lo interesante en el modo radicalmente opuesto de usar el mismo material de archivo (ambos filmes incorporan imágenes de La insurrección cultural y de Victoria de un pueblo en armas) es que hace evidente el carácter no referencial del cine documental, al resaltar la importancia del montaje y el guión para significar las imágenes mostradas.

En el contexto de Centroamérica, cabe resaltar que esta propuesta cinematográfica de Mercedes Moncada comparte con las producciones de otras mujeres cineastas de la región la articulación de un lenguaje que desde la experiencia personal interviene en lo político. Estoy pensando en películas como Princesas rojas (2013) de Laura Astorga, El lugar más pequeño (2011) de Tatiana Huezo, El eco del dolor de mucha gente (2011) de Ana Lucía Cuevas o La Yuma (2010) de Florence Jaugey. Por último, en su recurso al formato documental, pero con una fuerte impronta argumental, Palabras mágicas también participa en las búsquedas del documentalismo latinoamericano

Hansen no era danés ni fotógrafo, sino un espía sandinista, pero no sabía que iba a poner una bomba" (Rodríguez y Gómez).

Revista Iberoamericana, Vol. LXXXI, Núm. 251, Abril-Junio 2015, 539-553 ISSN 0034-9631 (Impreso)

ISSN 2154-4794 (Electrónico) 
reciente en el cual el cine funciona como forma de indagación de la subjetividad individual en su vínculo con lo nacional. Tanto la experimentación con el medio como la confrontación, de sí mismo/a y del público forman parte de este nuevo cine. Por lo general, es un cine que molesta. Y es en esa molestia que reside su eficacia política. La apertura a los formatos mixtos, la irreverencia hacia los dogmas del género, le permiten a Mercedes Moncada desarrollar un lenguaje audiovisual novedoso que, a la larga, puede contribuir a una transformación de los modos de hacer cine en el istmo.

\section{OBRAS CITADAS}

Aguilar, Gonzalo. Otros mundos. Un ensayo sobre el nuevo cine argentino. Buenos Aires: Santiago Arcos Editor, 2005.

Benjamin, Walter. "Über den Begriff der Geschichte". Abhandlungen. Gesammelte Schriften I.2. Walter Benjamin. Frankfurt: Suhrkamp, 1991. 693-704.

Cortés, María Lourdes. La pantalla rota. Cien años de cine en Centroamérica. La Habana: Fondo Editorial Casa de las Américas, 2007.

Especialista Mike. "Palabras mágicas (para romper un encantamiento)". Filmaffinity.

28 mayo $2012<$ http://www.filmaffinity.com/es/reviews/1/100911.html>. 3 oct. 2013.

Last Chapter: Goodbye Nicaragua. Peter Torbiörnsson, dir. Eden Film: 2010.

Marx, Karl. Der achzehnte Brumaire des Louis Bonaparte. Leipzig: Reclam, 1982.

Medina, Julia. "Caricatura del sandinismo y de la resistencia en mutación". Istmo. Revista virtual de estudios literarios y culturales centroamericanos 20 (2010): 1-13. <http://istmo.denison.edu/n20/articulos/3-medina_julia_form.pdf $>.10$ ago. 2013.

"Retrato de resistencias en una fotografía de Augusto C. Sandino". Revista Iberoamericana LXXIX/242 (2013): 57-74.

Nicaragua... el sueño de una generación. Roberto Persano, Santiago Nacif Cabrera, dirs. Adart Producciones, 2012.

Palabras mágicas: para romper un encantamiento. Mercedes Moncada, dir. Amaranta Producciones, 2012.

Palacios, Adriana. "Memoria e Imagen. Palabras Mágicas". Carátula. Revista Cultural Centroamericana 53 (2013). <http://www.caratula.net/ediciones/53/ cine-apalacios.php>. 9 junio 2013.

Rodríguez, Ileana y Antonio Gómez. "Yuxtaposiciones: rostros, tiempos, máscaras". Carátula. Revista Cultural Centroamericana 52 (2013). <www.caraula.net/ ediciones/52/cine-rodriguez_gomez.php>. 5 nov. 2013.

Torres Rivas, Edelberto. Revoluciones sin cambios revolucionarios. Ensayos sobre la crisis en Centroamérica. Guatemala: F\&G Editores, 2011.

Revista Iberoamericana, Vol. LXXXI, Núm. 251, Abril-Junio 2015, 539-553 ISSN 0034-9631 (Impreso)

ISSN 2154-4794 (Electrónico) 
Vernik, Esteban. "Nación, memoria y revolución. Walter Benjamin y el salto del tigre". III Seminario Internacional Políticas de la Memoria "Recordando a Walter Benjamin: Justicia, Historia y Verdad. Escrituras de la Memoria”. Buenos Aires, 28,29 y 30 de octubre de 2010. 
